\title{
Aplikasi Pendukung Penetapan Harga Produk Untuk Usaha Mikro, Kecil, dan Menengah (UMKM) Berbasis Web Responsive
}

\author{
Rizki Wahyudi \\ Program Studi Teknik Informatika, STMIK Amikom Purwokerto, Indonesia \\ Email: rizki.key@gmail.com
}

\begin{abstract}
Abstrak
Penelitian ini bertujuan untuk membuat rancang bangun aplikasi penunjang penetapan harga pada Usaha Mikro, Kecil, dan Menengah (UMKM). Penetapan harga produk merupakan hal yang penting, salah satunya dari aspek biaya, agar produk yang di jual dapat memberi keuntungan bagi perusahaan. Dalam penetapan harga, perusahaan harus memperhatikan biaya produksi dan nonproduksi, secara umum ada 4 variabel utama yang harus di masukkan dalam perhitungan harga produk yaitu Biaya Bahan Baku, Biaya Tenaga Kerja, Biaya Overhead pabrik Tetap maupun Variabel dan Biaya nonproduksi. Agar penelitian dapat terarah, maka digunakan metode pengembangan sistem Extreme Programming yang berorientasi objek, dapat dikerjakan dengan tim kecil, dan interaksi yang inten dengan user dapat memaksimal pengembangan sistem yang efektif dan efesien. Tahapan Extreme Programming, Planning, Design, Coding, dan Testing. Diharapkan dengan adanya aplikasi penetapan harga perusahaan dapat memaksimalkan keuntungan melalui proses perhitungan penetapan harga. Berdasarkan hasil pengujian Blackbox Testing, semua fungsional sistem pada aplikasi bekerja dengan baik.
\end{abstract}

Kata Kunci: Aplikasi, Penetapan Harga, Produk, Extreme Programming, Web Responsif

\begin{abstract}
This study aims to create a design for supporting pricing applications in Micro, Small and Medium Enterprises (MSMEs). Determination of product prices is an important thing, one of them from the aspect of costs so that products sold can provide benefits for the company. In pricing, companies must pay attention to production and nonproduction costs, in general, there are 4 main variables that must be included in the calculation of product prices namely Raw Material Costs, Labor Costs, Fixed Factory Overhead Costs and Variables, and Nonproduction Costs. In order for research to be directed, then the method of developing an Extreme Programming system is object-oriented, it can be done with a small team, and interactions that are intent- live with the user can maximize the development of an effective and efficient system. Stages of Extreme Programming, Planning, Design, Coding, and Testing. It is expected that with the pricing application the company can maximize profits through the price determination process. Based on the results of the Blackbox Testing test, all functional systems on the application work well.
\end{abstract}

Keywords: Applications, Pricing, Product, Extreme Programming, Responsive Web

\section{PENDAHULUAN}

Penggunaan komputer tidak hanya pada satu bidang saja melainkan sudah mencakup pada semua aspek kegiatan usaha baik bidang usaha besar maupun kecil. Dengan melihat persaingan dalam dunia usaha pada saat sekarang, semakin tampak jelas kegiatan yang bergerak dibidang ekonomi salah satunya Usaha Mikro, Kecil, dan Menengah (UMKM). membuat komputer sangat berpengaruh, karena proses pengolahan data dapat diselesaikan dengan cepat dan efisien.

UMKM mempunyai peran penting dalam pembangunan ekonomi nasional, namun dalam pengelolaan nya, terdapat hambatan-hambatan baik yang bersifat internal maupun eksternal. Hambatan internal diantaranya UMKM belum memiliki sistem administrasi keuangan dan manajemen yang baik Kementrian Perindustrian Republik Indonesia [1], Bank Indonesia [2]. Salah satu permasalahan utamanya adalah kurangnya pengetahuan UMKM, mengenai cara penetapan harga khususnya dari aspek biaya yang dikeluarkan selama proses produksi, mengakibatkan kurangnya maksimal pendapatan yang didapatkan dari penjualan produk. Dibanyak kasus variabel pemasaran dan administrasi umum tidak dimasukkan dalam perhitungan harga produk, hal ini diperkuat oleh Kemenkop UKM [3] persoalan manajemen keuangan seringkali menjadi salah satu kelemahan utama UMKM dalam mengembangkan usahanya, sumber daya yang dimiliki tidak kompeten dalam menentukan harga pokok produksi.

Menurut Mulyadi [4] Harga pokok produksi untuk pembuatan produk terdapat dua jenis biaya yaitu biaya produksi dan biaya nonproduksi. Biaya produksi adalah biaya-biaya yang dikeluarkan untuk pengolahan bahan baku menjadi produk, sedangkan biaya nonproduksi adalah biaya-biaya yang dikeluarkan untuk kegiatan nonproduksi, seperti kegiatan pemasaran dan kegiatan administrasi umum. Biaya yang dikeluarkan untuk produksi membentuk harga pokok produksi, yang digunakan dalam menghitung harga pokok produk yang pada akhir periode akuntansi masih dalam proses. Biaya nonproduksi ditambahkan pada harga pokok produksi untuk menghitung total harga pokok produk.

Data yang digunakan untuk studi kasus pada penelitian ini diambil dari penelitian yang sudah dilakukan olehTripustikasari \& Wahyudi [5] mengenai analisis metode penetapan harga produk pada perusahaan, pada penelitian ini membandingkan metode penetapan harga menggunakan Full Costing dan Variabel Costing. Berdasarkan penelitian tersebut untuk memaksimalkan penetapan harga produk maka metode Full Costing lebih baik jika dilihat dari aspek biaya karena memasukkan semua varibael yang digunakan pada proses produksi yaitu variabel Biaya Bahan Baku, Biaya Tenaga Kerja, Biaya Overhead Pabrik Variabel/Tetap dan Biaya nonproduksi. 
Penelitiaan mengenai rancang bangun aplikasi penentuan harga juga pernah dilakukan oleh Jatmiko, dkk [6] penelitian ini bertujuan untuk penetapan harga pokok menggunakan metode Full Costing dengan cara menghitung harga pokok produksi dan nonproduksi seta mencari penambahan biaya Markup.

Agar penelitian dapat terarah, maka digunakan metode pengembangan sistem Extreme Programming yang berorientasi objek, dapat dikerjakan dengan tim kecil, dan interaksi yang inten dengan user dapat memaksimal pengembangan sistem yang efektif dan efesien. Tahapan Extreme Programming, Planning, Design, Coding, dan Testing [7]. Aplikasi dibangun berbasis Web Responsif, agar dapat di akses dari mana saja menggunakan akses internet. Menurut Lutfi \& Wahyudi [8] Web Responsif merupakan pendekatan yang memberikan kemampuan Web/situs beradaptasi dengan pengguna situs dan lingkunagn Web/situs. Diharapkan dengan adanya aplikasi penetapan harga perusahaan dapat memaksimalkan keuntungan melalui proses perhitungan penetapan harga.

\section{TEORITIS}

\subsection{Metode Pengembangan Sistem}

Metode pengembangan sistem merupakan suatu proses pengembangan sistem yang terstruktur dan sistematis yang mendefinisikan serangkaian aktivitas, metode dan tools yang terautomasi bagi para pengembang dalam rangka mengembangkan dan merawat sebagai keseluruhan sistem informasi. Pada penelitian ini metode pengembangan yang digunakan adalah metode Extreme Programing kerangka kerja Extreme Programing dapat dilihat pada Gambar 1.

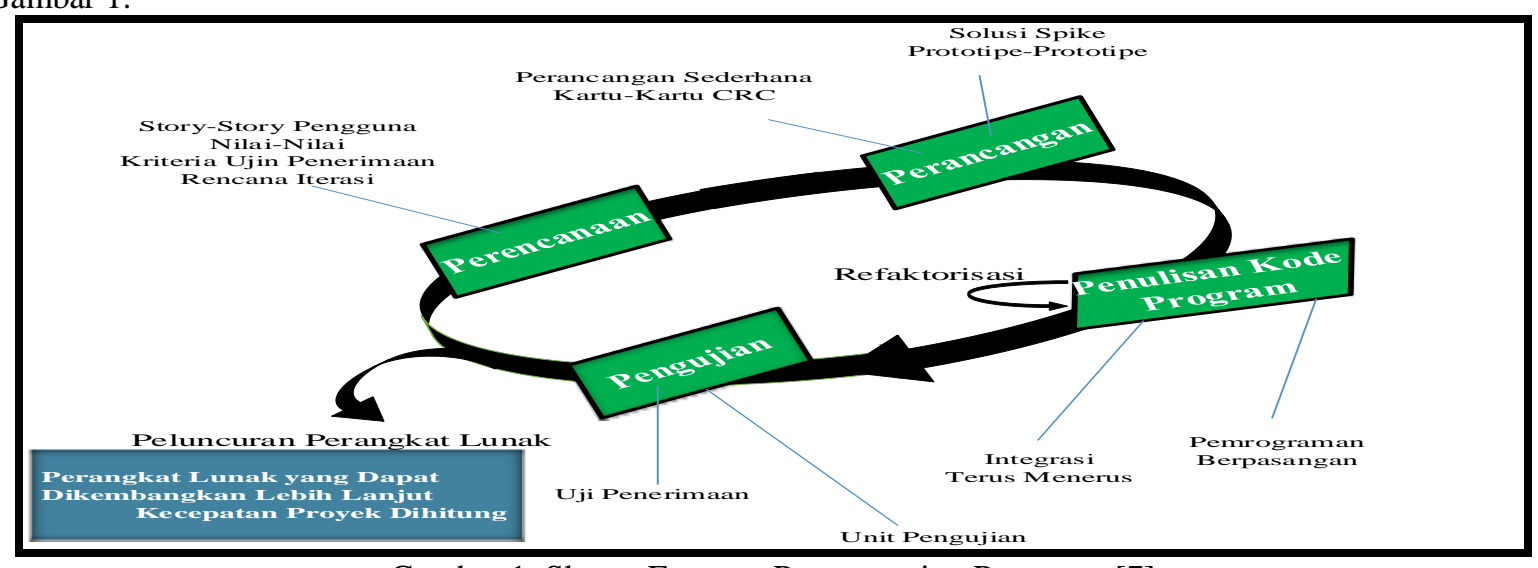

Gambar 1. Skema Extreme Programming Pressman [7]

Adapun proses dan tahapan Extreme Programming yaitu:

a. Perencanaan

Pada tahap perencanaan dilakukan pemahaman terhadap konsep bisnis, pengumpulkan kebutuhan sistem, menggambarkan keluaran yang diperlukan, fitur - fitur, dan fungsionalitas - fungsionalitas yang akan dibangun menggunakan rekayasa perangkat lunak.

b. Perancangan

Berdasarkan data yang diperoleh dari tahap perencanaan analisis kebutuhan sistem, keluaran sistem, fitur-fitur, fungsionalitas maka sistem dirancang menggunakan Unified Modelling Langguage (UML) manfaat penggunaan modelling yang sudah memiliki standar adalah untuk memastikan bahwa sistem yang akan dibangun dapat diselesaikan dengan tepat waktu, sesuai dengan anggaran, dan sesuai dengan spesifikasi yang ditetapkan pada tahap perencanaan.

c. Pengkodean

Pada tahap pengkodean tim kecil akan bekerja secara bertahap dengan panduan alur sistem yang sudah dirancang pada tahap design modul per modul. Dengan refactoring, mudah dibaca dan dimodifikasi yang merupakan ciri khas Metode Extreme Programming diharapkan pengembangan sistem dengan tim kecil menjadi cepat.

d. Pengujian

Pada penelitian ini pengujian, akan dilakukan beta testing untuk mendapatkan feedback tentang aplikasi memastikan semua fungsional sistem dapat bekerja dengan baik.

\section{ANALISA DAN PEMBAHASAN}

Untuk pengembangan sistem pada penelitian ini menggunakan metode Extreme Programming (XP) yang merupakan salah satu metode yang tergolong kedalam Agile Methodology 


\subsection{Perencanaan}

1. Rancangan Sistem Basis Data

Pada rancangan file ini akan dirancang semua field-field yang nanti akan berguna sebagai input data dalam rancangan program peneliti.

2. Rancangan Login

Pada rancangan Login ini peneliti rancang untuk membatasi pengguna sistem

3. Rancangan Input

4. Pada rancangan input ini peneliti merancang bentuk dari input-input data yang akan di proses dan dalam rancangan input inilah peneliti juga menampilkan prosedur untuk menghapuskan data, menambah data, mengedit data, mencari data dan keluar yang mana fungsi tombol keluar untuk kembali kemenu utama.
a. Form Bahan Baku
b. Form Biaya Tenaga Kerja
c. Form Biaya Overhead Pabrik
d. Form Biaya Non Produksi
e. Form Perhitungan Full Costing
f. Hasil Perhitungan

5. Rancangan Menu

Pada rancangan menu ini peneliti menggabungkan semua hasil program yang peneliti buat sehingga menjadi sebuah aplikasi yang bisa dijalankan lewat menu untuk menampilkan semua input data, laporan informasi dan lain sebagainya.

6. Rancangan Output

Pada rancangan output ini akan menampilkan bentuk output dari hasil perhitungan penetapan harga produksi.

\subsection{Perancangan}

Perancangan XP dengan ketat mengikuti prinsip "tetap sederhana". Sebuah hasil perancangan yang sederhana selalu lebih disukai daripada Gambaran - Gambaran yang lebih kompleks. Selain itu, perancangan XP akan memberikan panduan implementasi untuk suatu cerita ketika cerita itu ditulis, tidak kurang, tidak lebih. Rancangan - rancangan dan fungsionalitas - fungsionalitas yang ditambahkan (karena pengembang akan menganggap nantinya akan diperlukan) tidak terlalu disarankan.

1. Use case

a) Use case Penetapan Harga Produk

Pada Use case penetapan harga produk

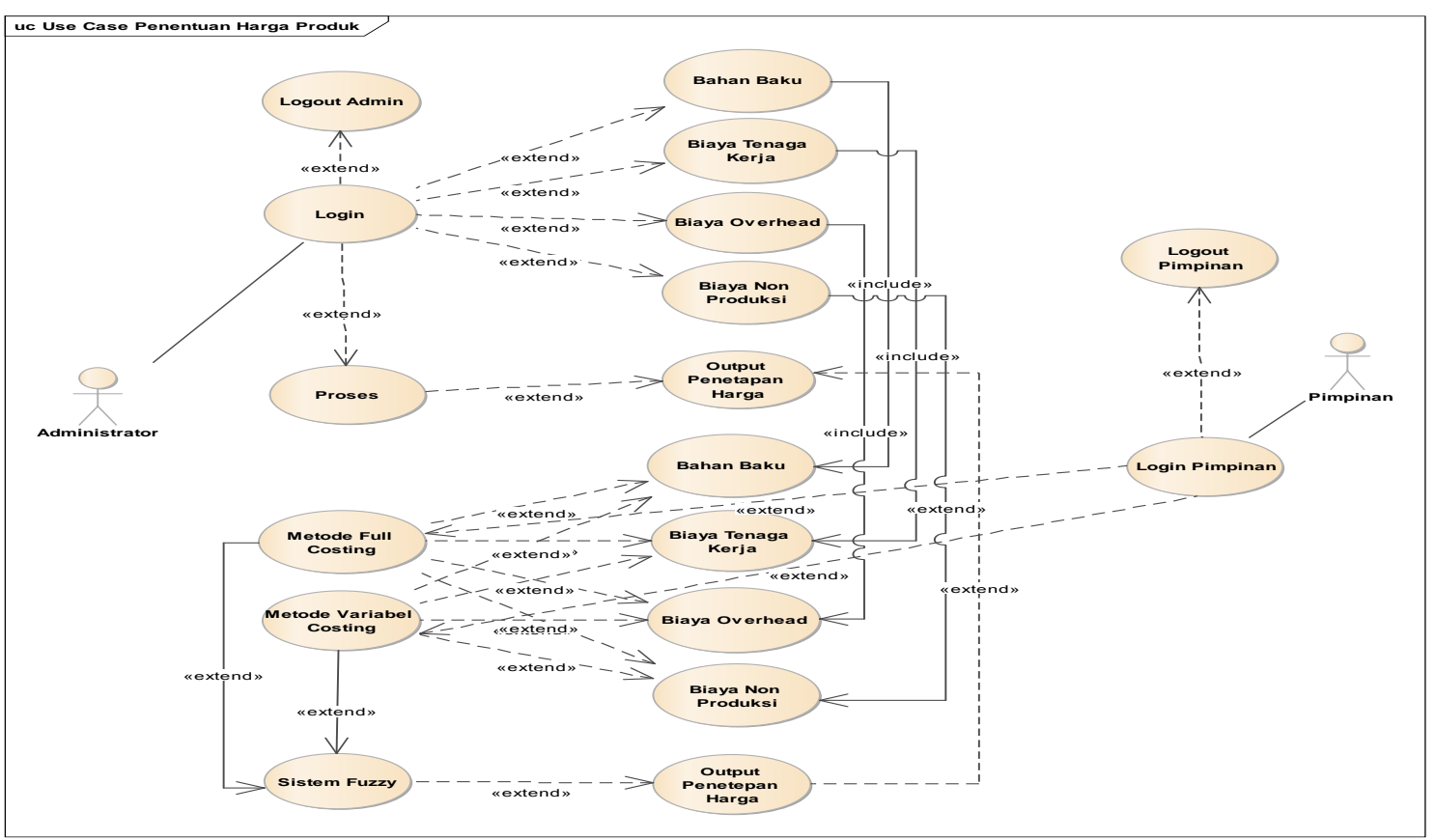

Gambar 2. Use case Penetapan Harga

Pada Gambar 2. Use case Penetapan Harga terdapat dua aktor yang terlibat dalam proses penetapan harga, aktor administrator dan Aktor pimpinan. 
JURNAL MEDIA INFORMATIKA BUDIDARMA, Vol 3, No 2, April 2019

ISSN 2614-5278 (media cetak)

ISSN 2548-8368 (media online)

Hal 105-116 | DOI: 10.30865/mib.v3i2.1107

a) Activity Diagram Admin Login

Aktivitas yang dilakukan untuk melakukan Login admin dapat dilihat seperti pada Gambar 3.

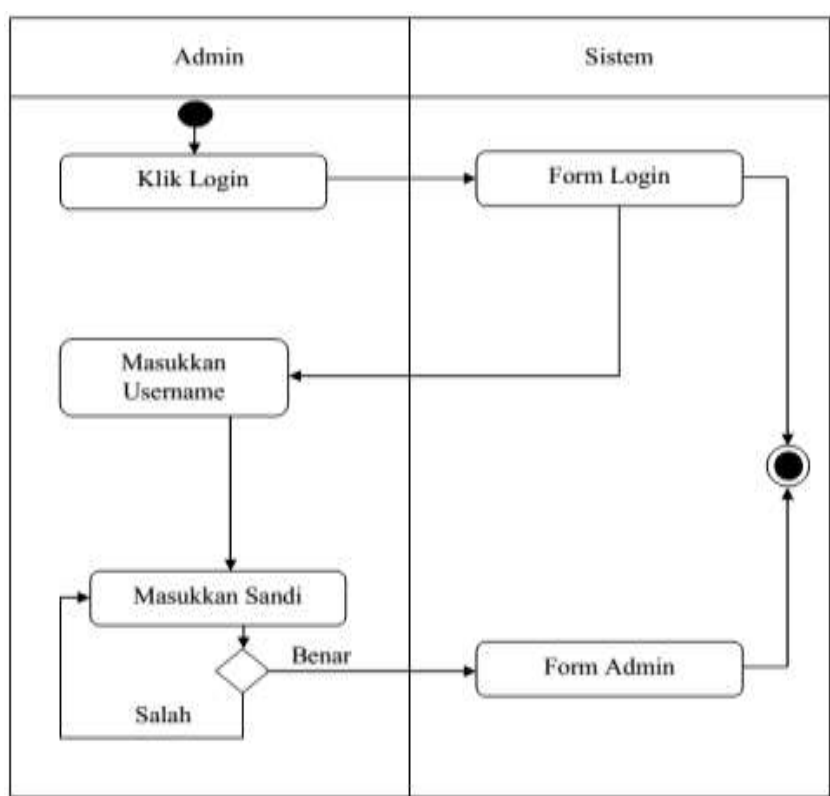

Gambar 3. Activity Diagram Admin Login

c) Activity Diagram Form masukan Bahan Baku

Sequence Diagram data Bahan Baku dapat dilihat seperti pada Gambar 4.

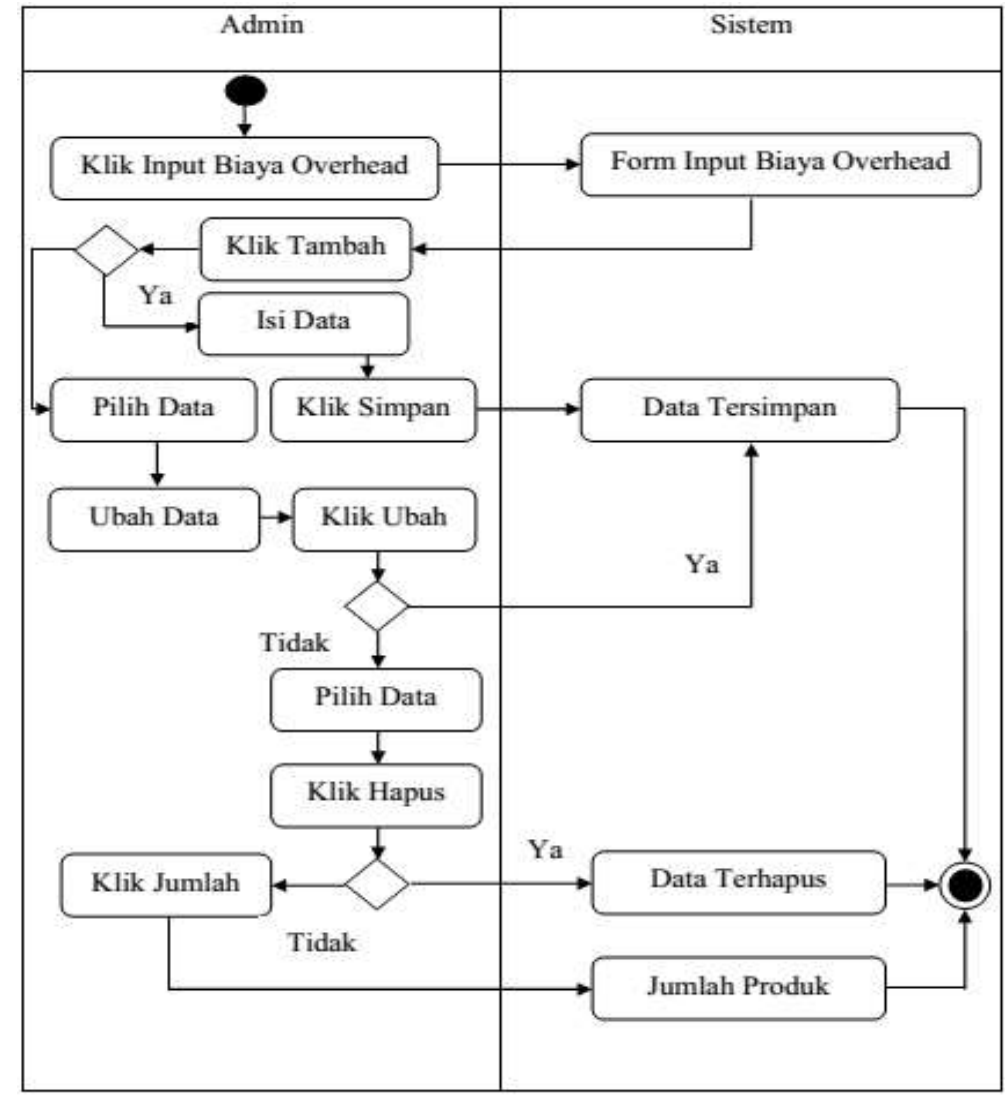

Gambar 4. Activity Form input Bahan Baku

d) Activity Diagram Form masukan Biaya Overhead

Sequence Diagram data Biaya Overhead dapat dilihat seperti pada Gambar 5. 


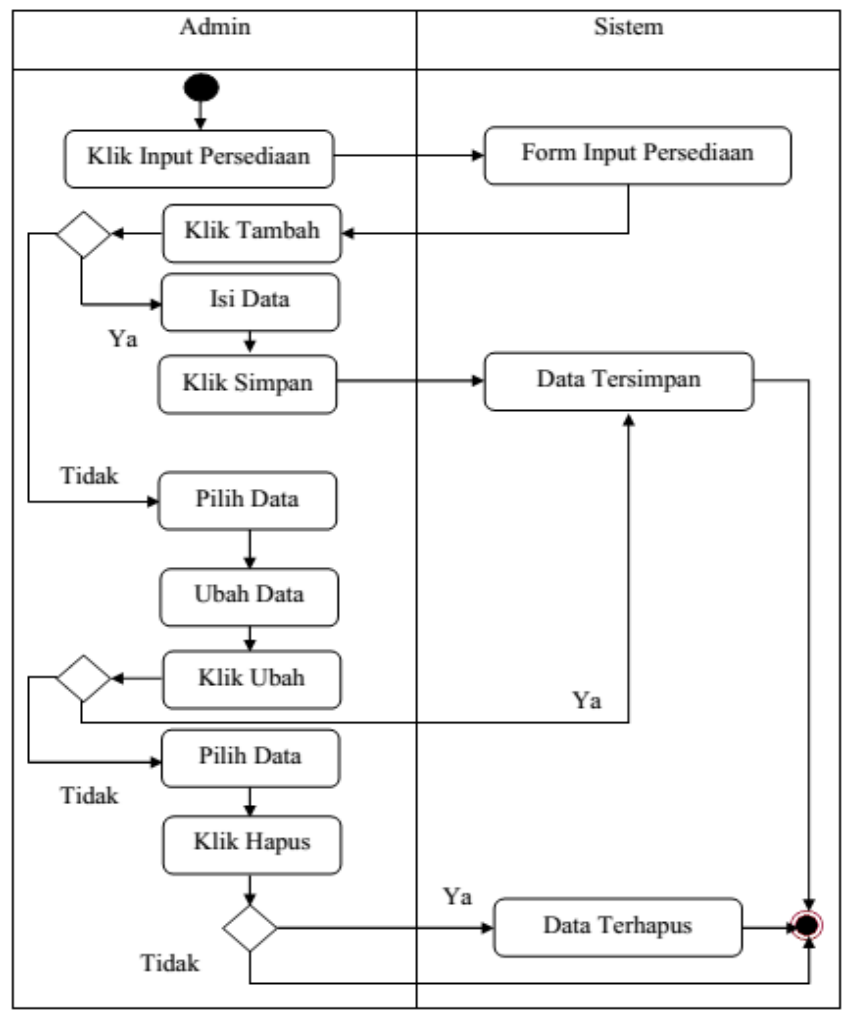

Gambar 5. Activity Diagram Form masukan Biaya Overhead

e) Activity Diagram Form masukan Biaya Produksi

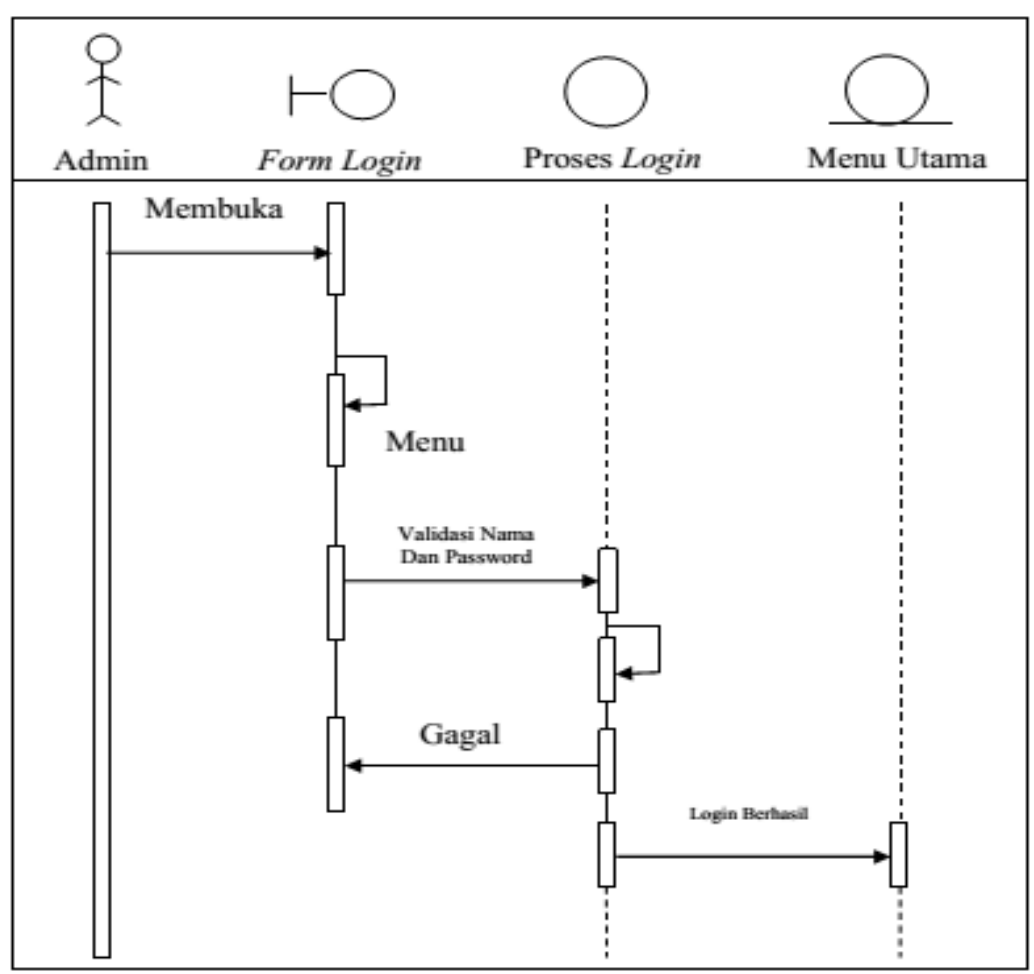

Gambar 6. Activity Diagram Form masukan Biaya Produksi

3. Sequence Diagram

Rangkaian kegiatan yang terjadi event sistem digambarkan pada Sequence Diagram berikut: a) Sequence Diagram Admin Login

Serangkaian kerja melakukan Login admin dapat terlihat seperti pada Gambar 7. 


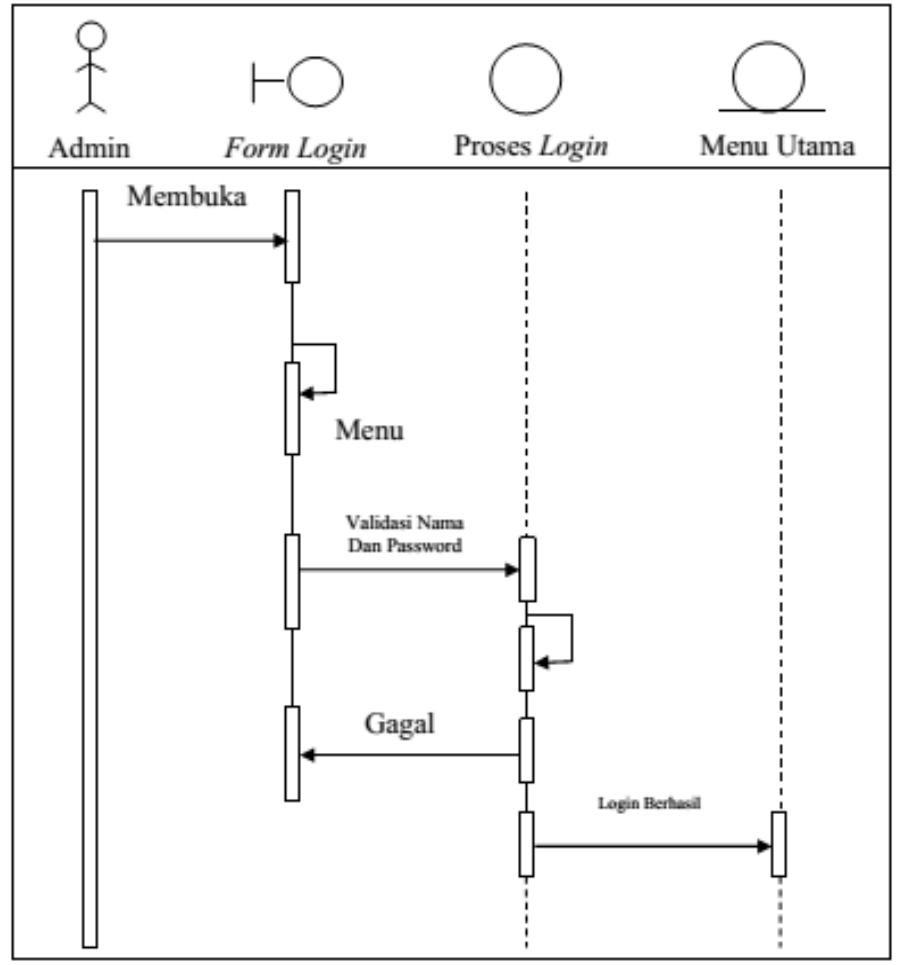

Gambar 7. Sequence Diagram Form Login

b) Sequence Diagram Bahan Baku

Sequence Diagram data Bahan Baku dapat dilihat seperti pada Gambar 8.

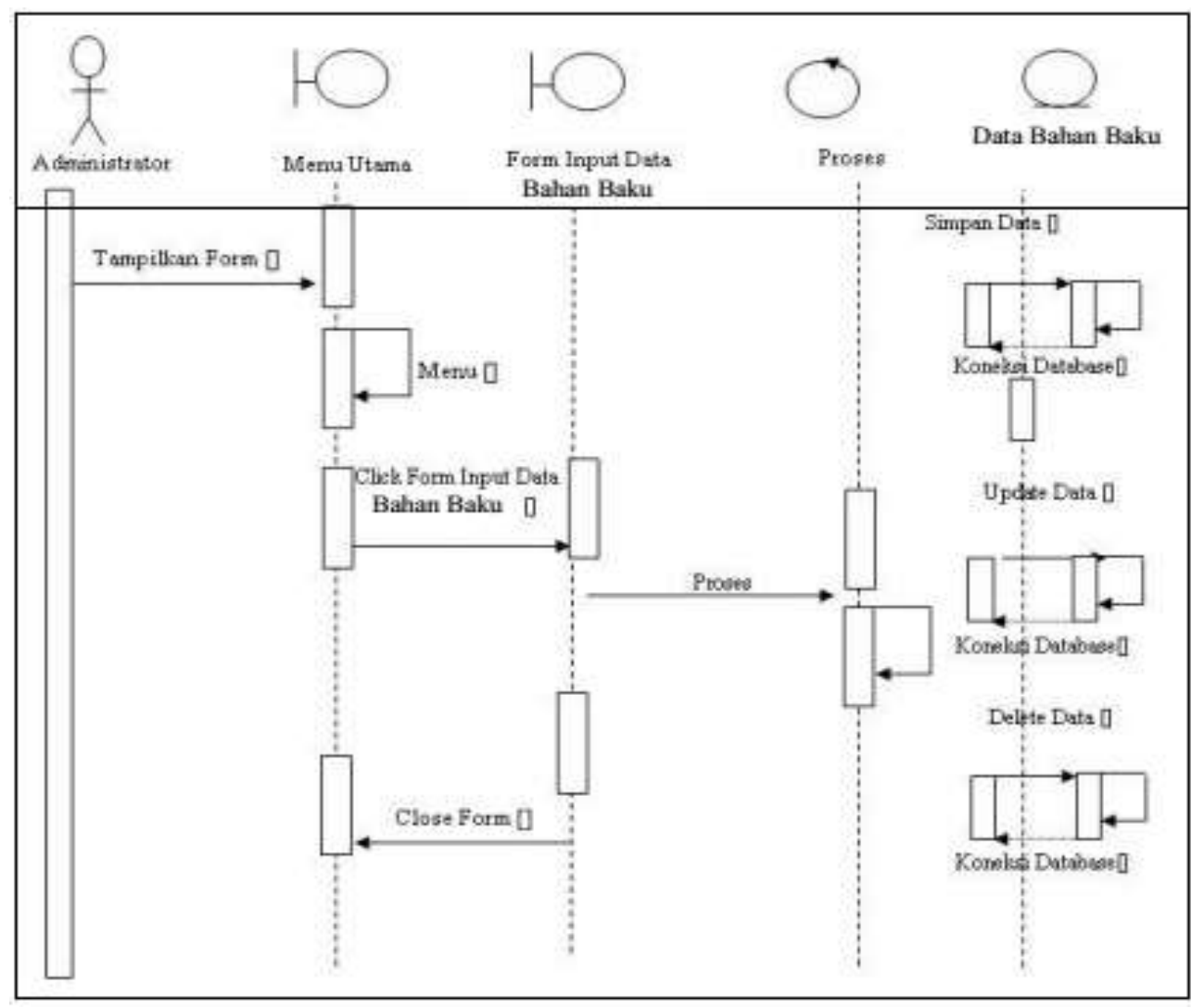

Gambar 8. Sequence Diagram Form Bahan Baku

c) Sequence Diagram Biaya Overhead

Sequence Diagram data Biaya Overhead dapat dilihat seperti pada Gambar 9. 


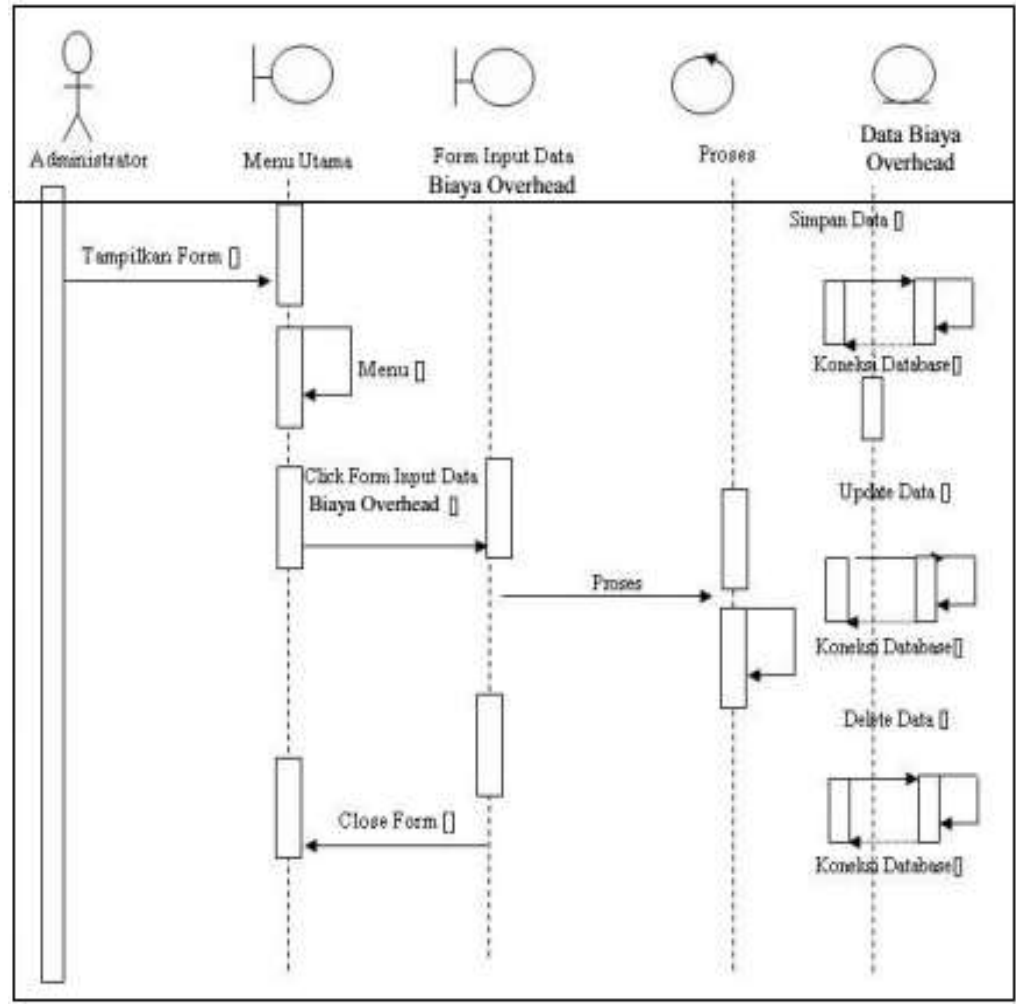

Gambar 9. Sequence Diagram masukan Biaya Overhead

d) Sequence Diagram Biaya Produksi

Sequence Diagram data Biaya Produksi dapat dilihat seperti pada Gambar 10.

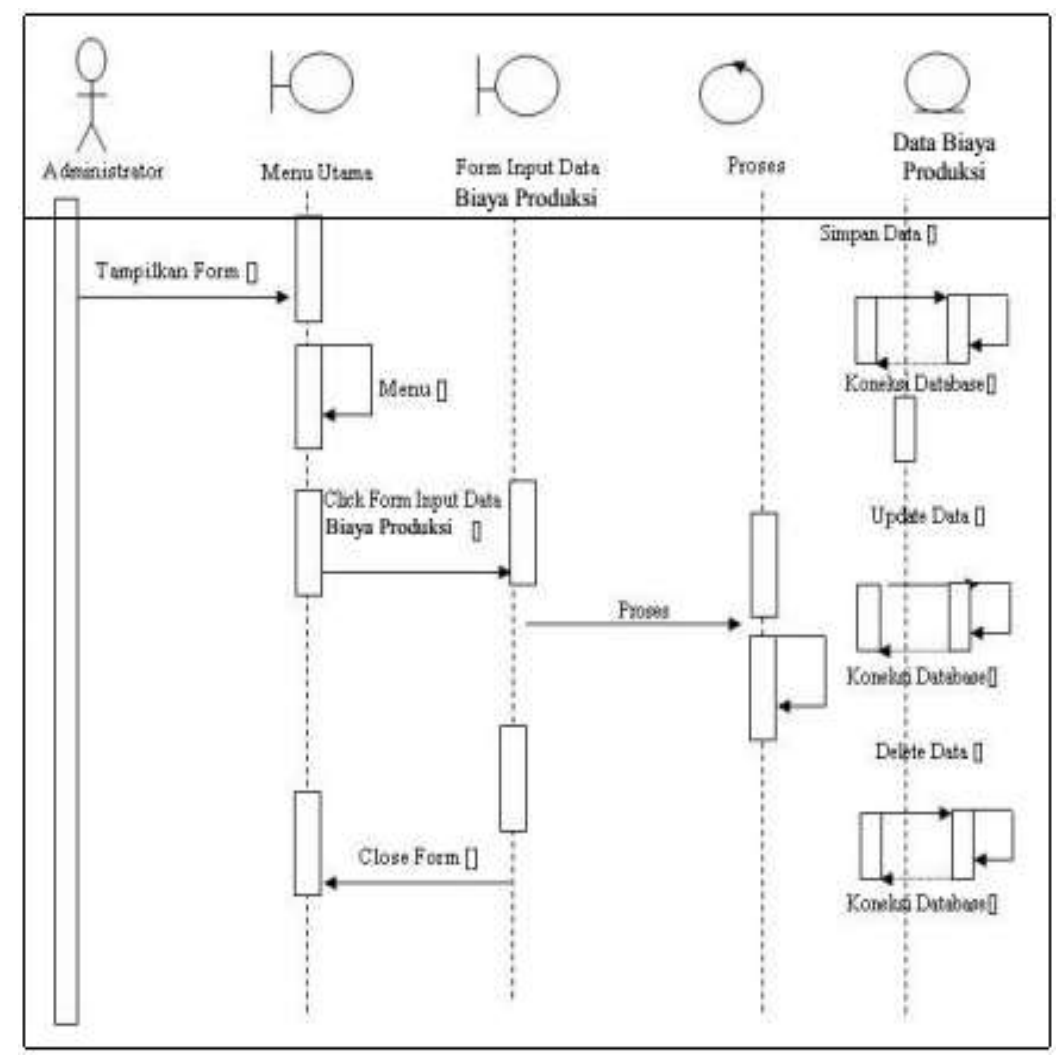

Gambar 10. Sequence Diagram Masukan Biaya Produksi

4. Class Diagram 


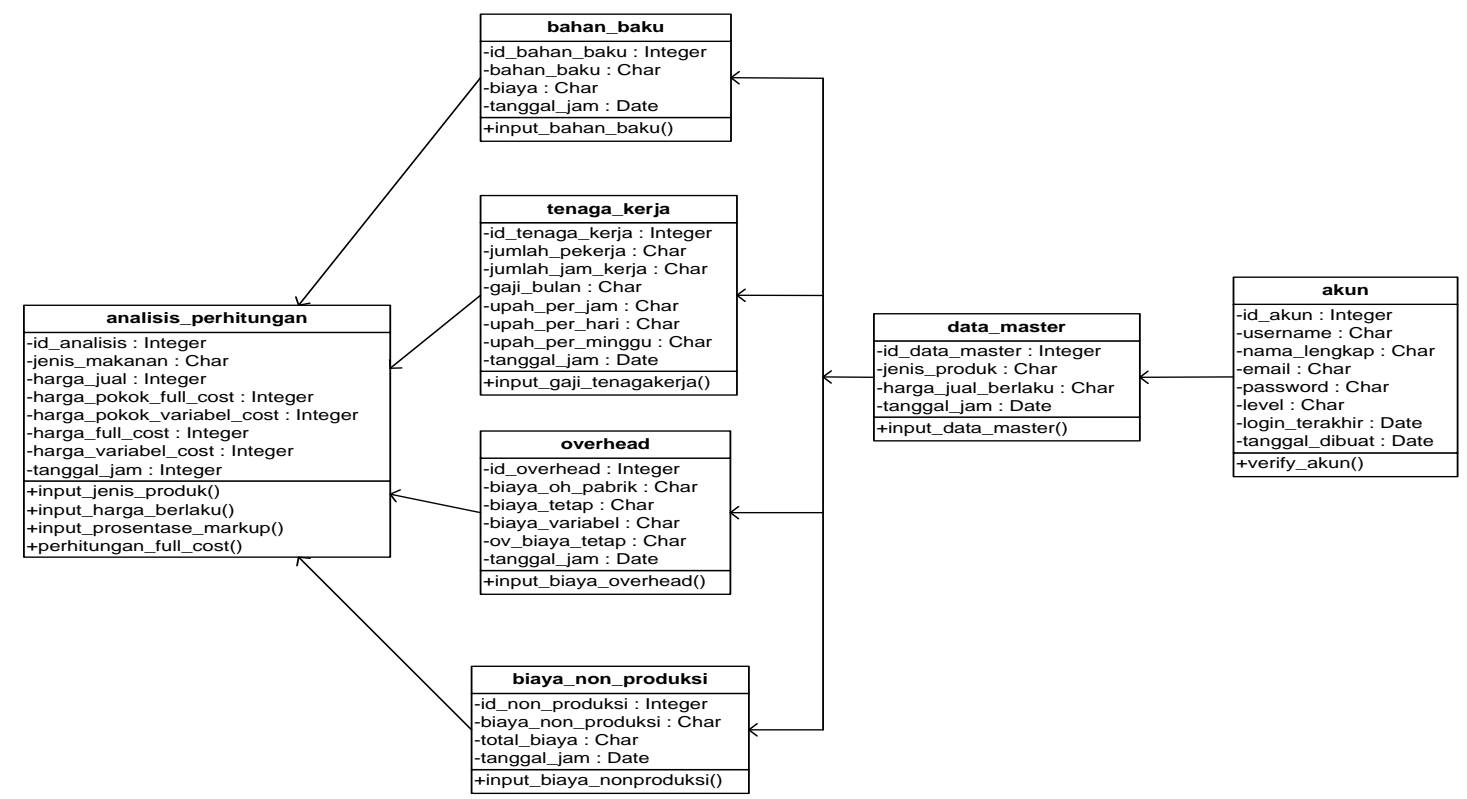

Gambar 11. Class Diagram

\section{IMPLEMENTASI}

\subsection{Implementasi Tatap Muka}

Implementasi user interface berikut merupakan tampilan program yang digunakan user untuk melakukan proses perhitungan penetapan harga meliputi Variabel Bahan Baku, Tenaga Kerja, Overhead Pabrik, Biaya Non Produksi, Form Perhitungan (Perhitungan Harga Pokok Produksi dan Harga Jual Pendekatan Full Costing, Perhitungan Harga Pokok Produksi) dan Tampilan Hasil Perhitungan Harga.

a) Halaman Login

Halaman Login dipergunakan untuk membatasi hak akses sistem hanya kepada pihak yang diberi akses admin dan pimpinan dengan memasukkan username dan password. Admin dan Pimpinan memiliki level akses yang sama bisa mengakses semua fitur pada sistem penetapan harga yang dapat dilihat pada Gambar 12.

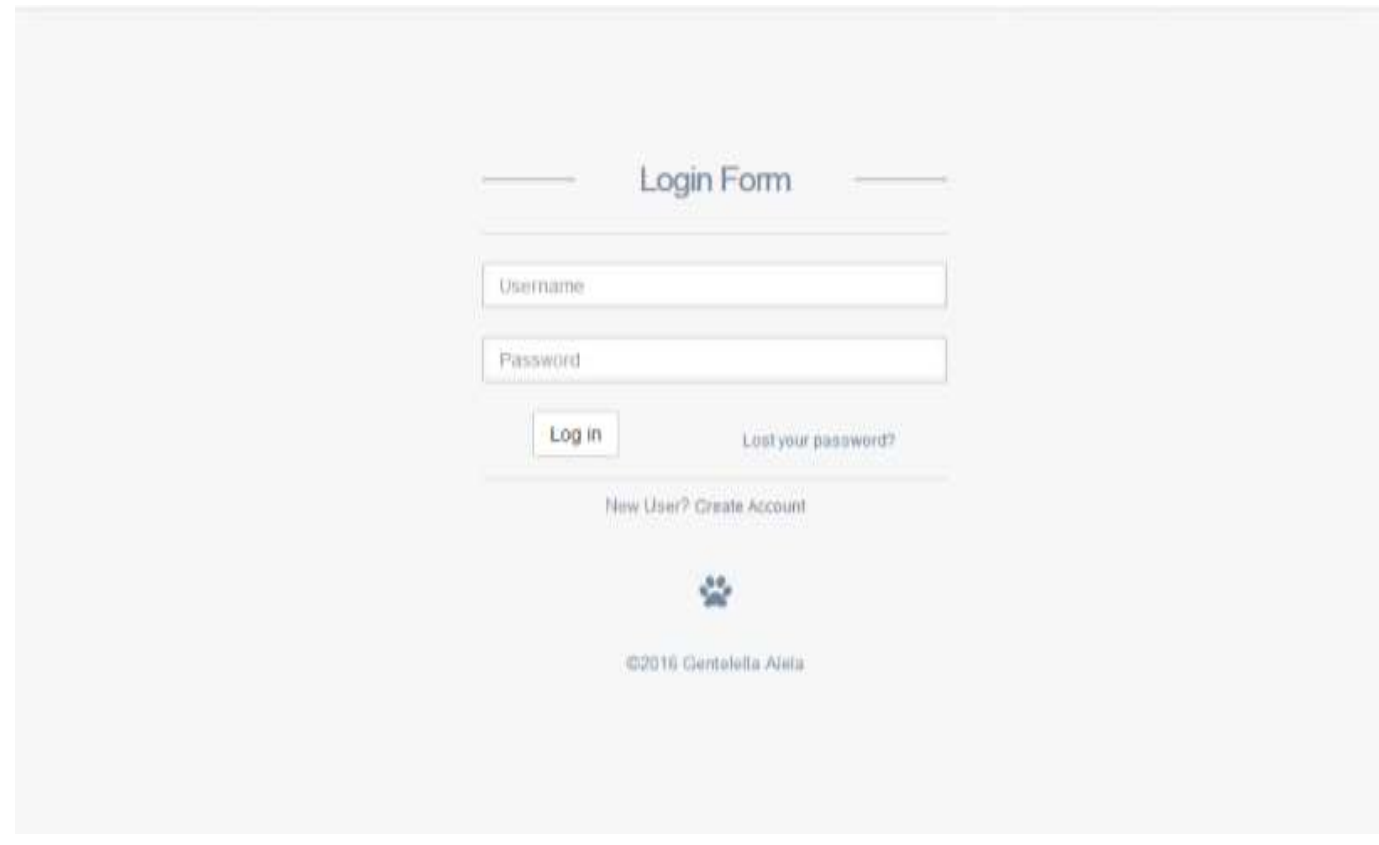

Gambar 12. Halaman Login

b) Halaman masukan Bahan Baku 

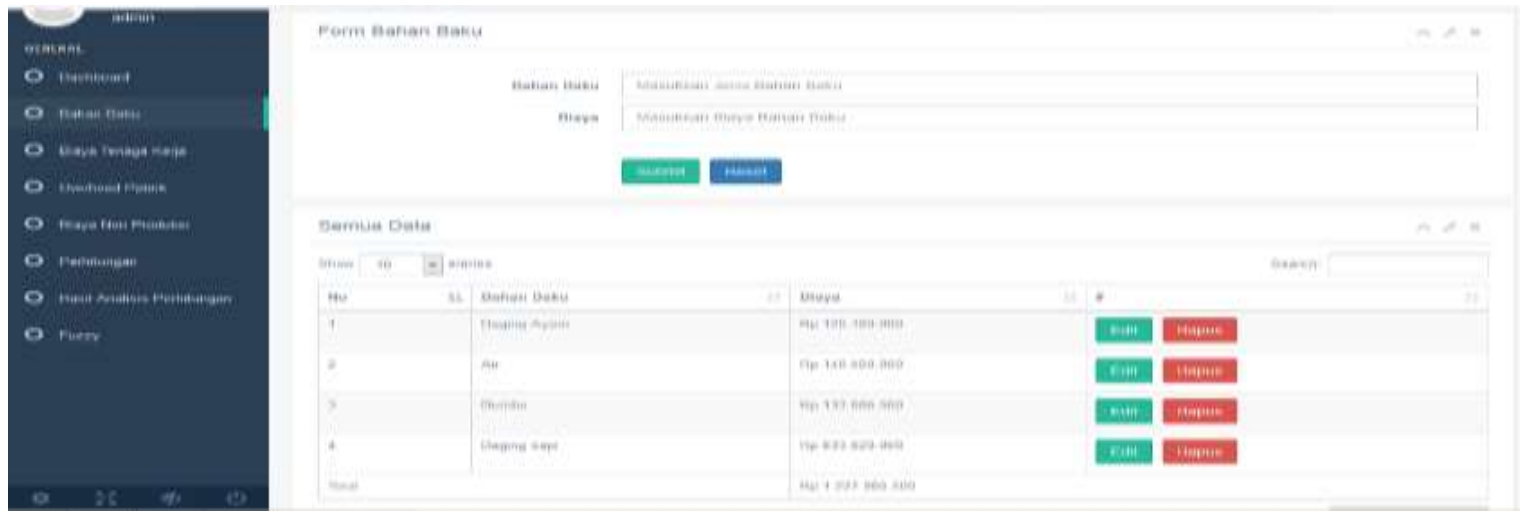

Gambar 13. Form Bahan Baku

Gambar 13. Form Bahan Baku merupakan Form masukan terdiri dari input Bahan Baku dan Biayanya. semua Bahan Baku dan Harga per-itemnya dapat dilihat juga pada tabel semua data yang ada pada Halaman Form Bahan Baku, kemudian pada menu ini juga dapat dilihat semua data Bahan Baku dan Harga disertai fungsi Edit dan Delete.

c) Form Biaya Tenaga Kerja
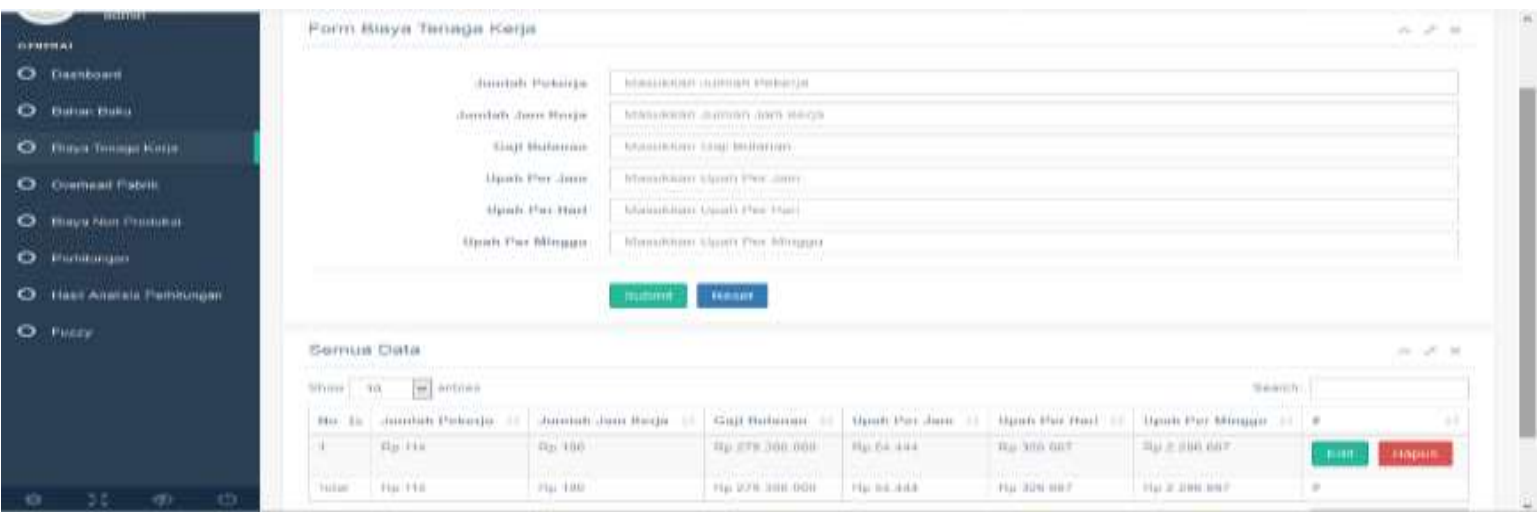

Gambar 14. Form Biaya Tenaga Kerja

Pada Gambar 14. Form biaya tenaga kerja digunakan untuk meng input, jumlah pekerja, jumlah jam kerja, gaji bulanan, upah perjam, upah perhari dan upah perminggu. kemudian pada menu ini juga dapat dilihat semua data biaya tenaga kerja yang dikeluarkan dan totalnya disertai fungsi Edit dan Delete.

d) Form Overhead Pabrik

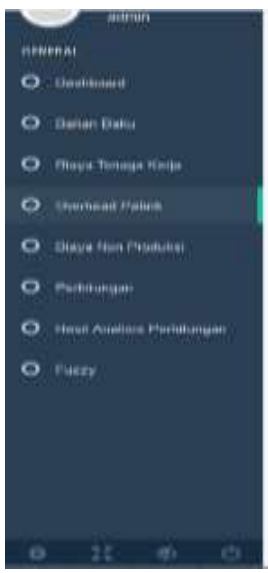

Ferm Biaya Overheas patio

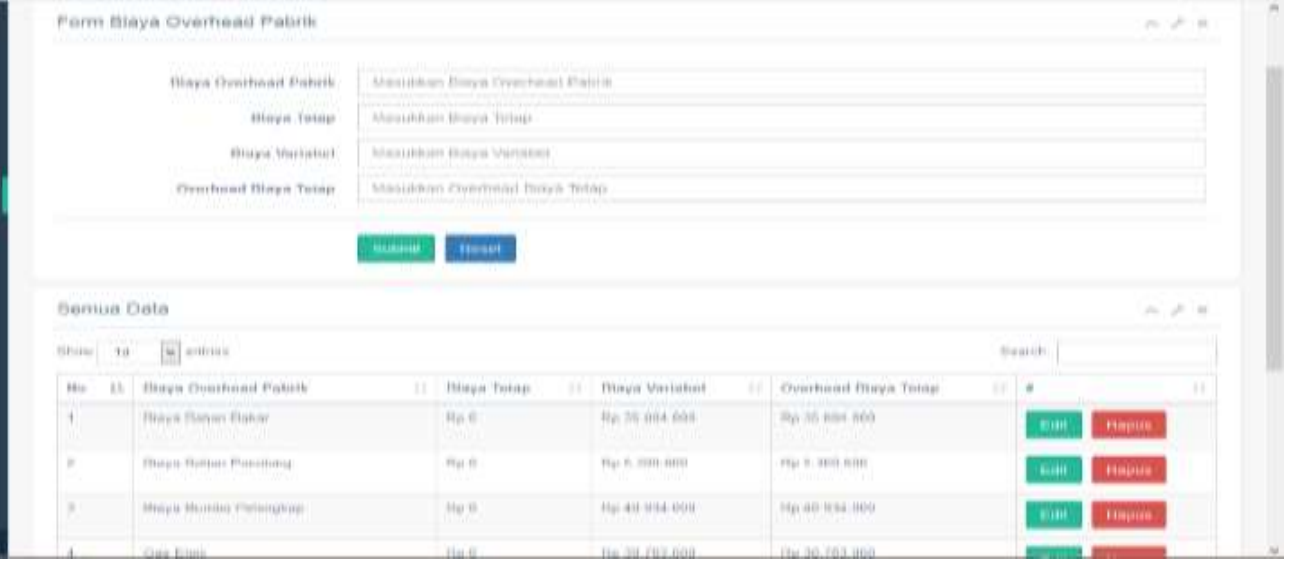

Gambar 15. Form Overhead Pabrik

Gambar 15. Form Overhead Pabrik merupakan Form input semua Biaya Overhead kemudian pada halaman ini juga dapat dilihat semua data Bahan Baku dan Harga.

e) Form Biaya Non Produksi 

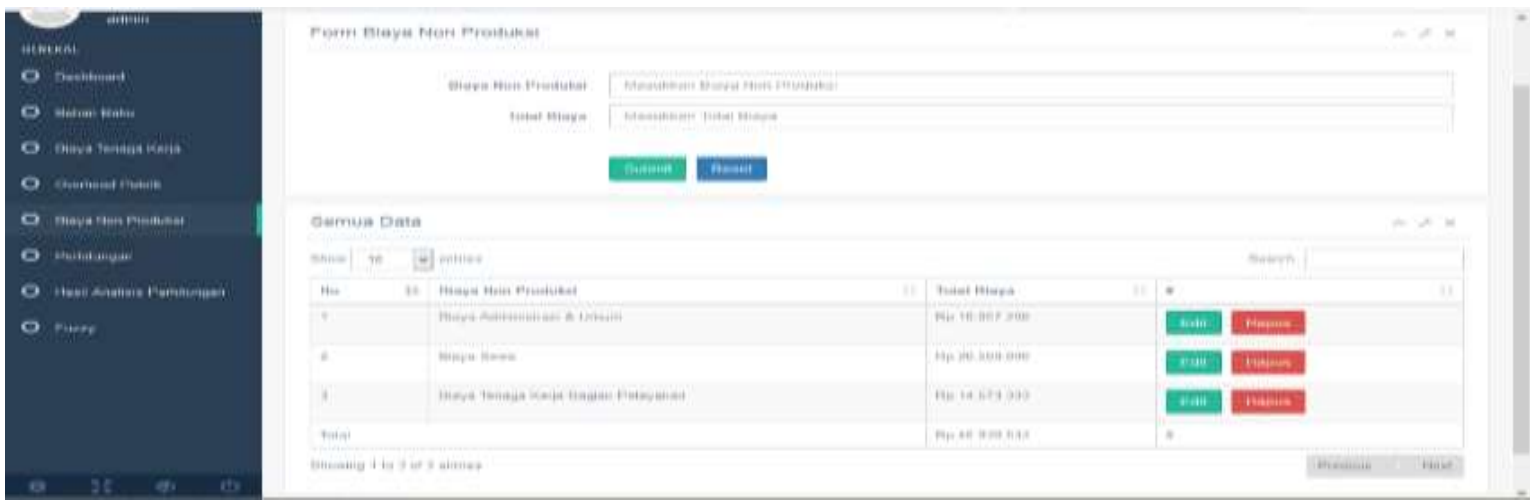

Gambar 16. Form Biaya Non Produksi

Gambar 16. Form Biaya Non Produksi merupakan Form input semua Biaya Non Produksi (Pemasaran, biaya Sewa dan biaya tenaga kerja bagian pelayanan). kemudian pada menu ini juga dapat dilihat semua data Biaya Non Produksi dan total Biaya yang dikeluarkan disertai fungsi Edit dan Delete.

f) Form Perhitungan Full Costing dan Variabel Costing
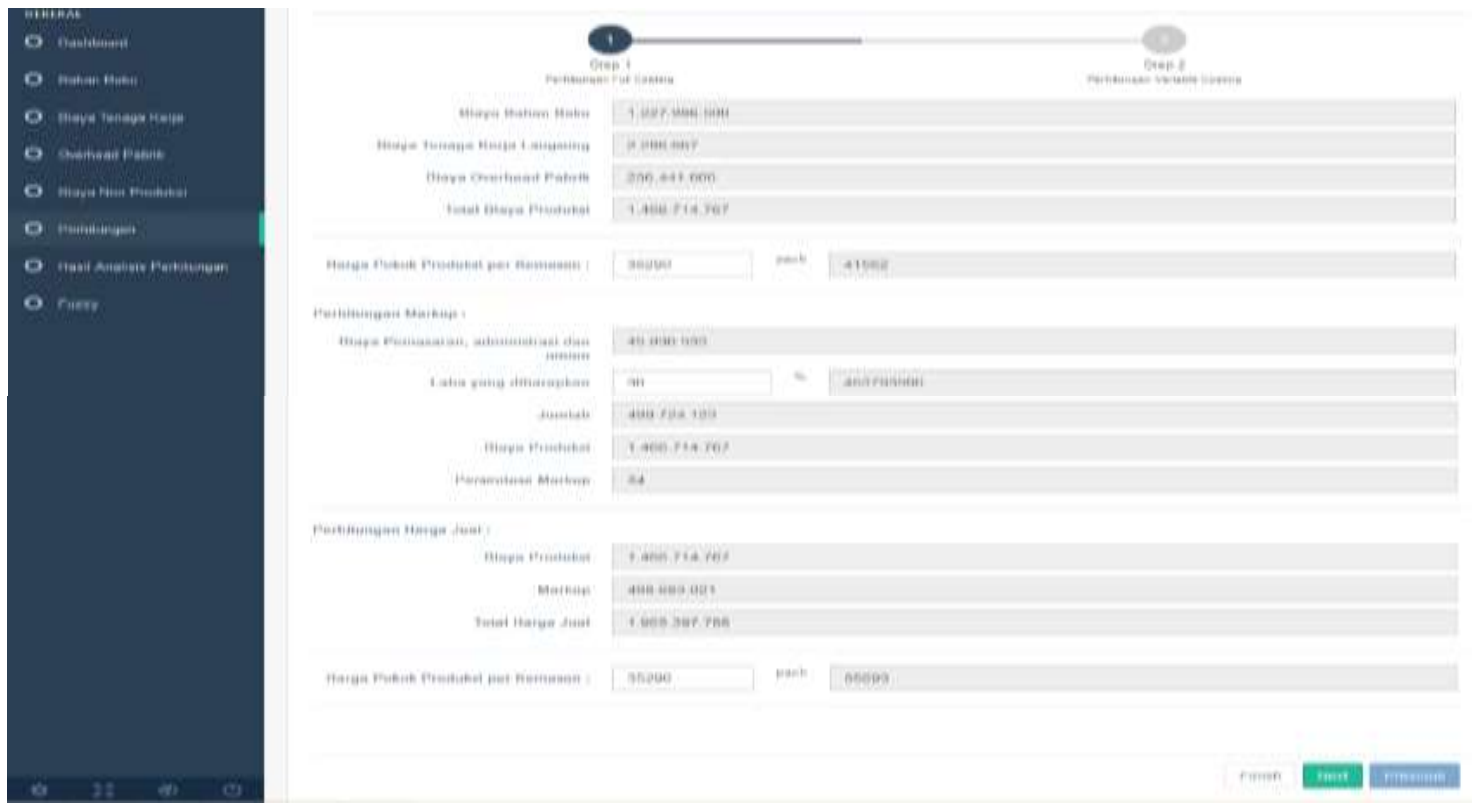

Gambar 17. Biaya Full Costing

Gambar 4.17. Form Peritungan Biaya Full Costing merupakan Form untuk perhitungan penetapan harga produk (Total biaya produksi, Prosentase laba yang diharapkan dan harga Mark up). kemudian pada menu ini juga dapat dilihat semua data Perhitungan Biaya Full Costing yang dikeluarkan.

g) Form Hasil Perhitungan Full Costing dan Variabel Costing

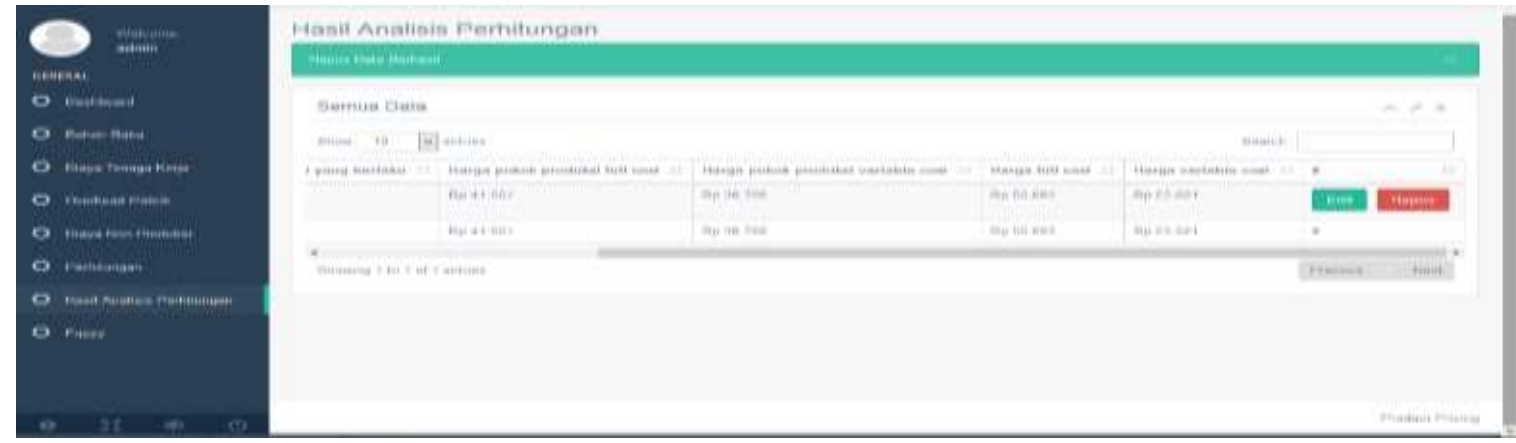

Gambar 18. Tampilan Hasil Perhitungan

Gambar 18. Merupakan halaman hasil perhitungan dapat dilihat nama produk, harga produk yang berlaku sekarang, biaya pokok produksi hinggal harga jual setelah dilakukan markup. 


\subsection{Pengkodean}

Dalam proses pengkodean, dilakukan per-module dimulai dari coding Form bahan baku, Form Overhead pabrik, Form tenaga kerja, Form biaya non produksi, Form perhitungan dan halaman hasil perhitungan. Berikut salah satu Screenshoot Javascript untuk pengambilan data proses dari tabel dan proses sebelumnya pada aplikasi pendukung penatapan harga, dapat dilihat pada Gambar 19.

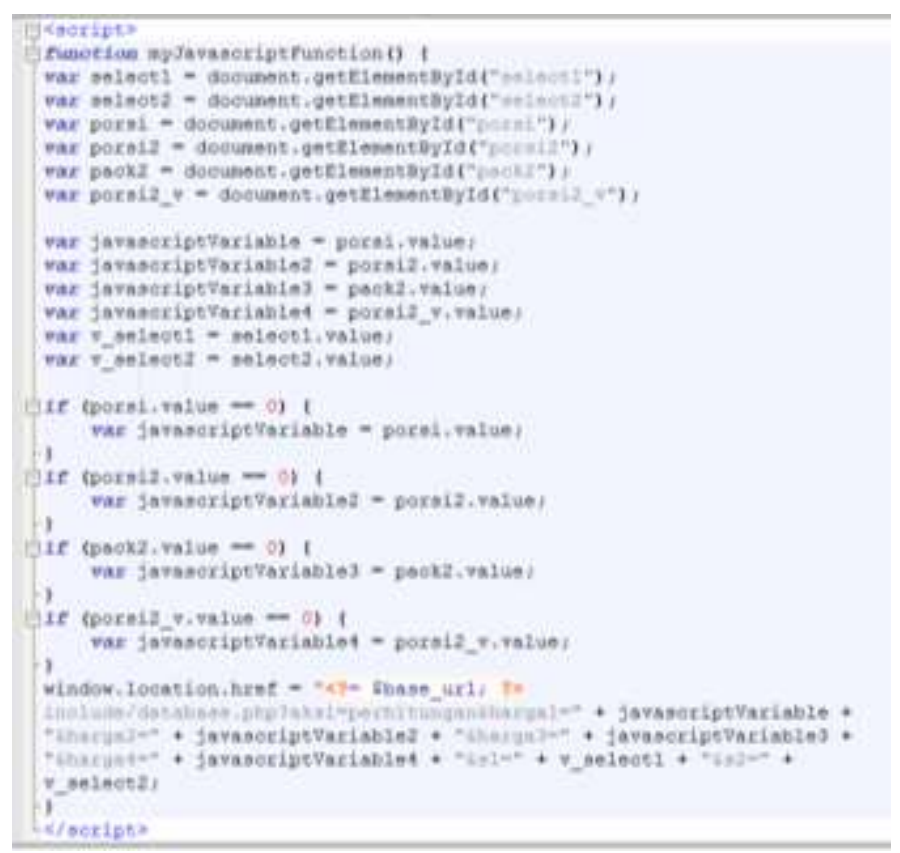

Gambar 19. Screenshoot Perhitungan Penetapan Harga menggunakan Javascript

Gambar 19. merupakan Screenshoot dari sebagian Perhitungan Penetapan Harga menggunakan Javascript. Menggunakan fungsi getElementById untuk mengakses property dan fungsi sebuah tag dengan hanya menunjuk ID nilai hasil proses dari perhitungan sebelumnya.

\subsection{Pengujian}

Pengujian unit testing dilakukan menggunakan metode Blackbox Testing untuk menguji fungsional sistem, berikut hasil pengujian Aplikasi pada Tabel 1.

Tabel 1. Pengujian Blackbox Testing

\begin{tabular}{|c|c|c|c|c|}
\hline No & Layout & Aksi & Hasil & Status \\
\hline 1 & Form Login & $\begin{array}{l}\text { Verifikasi untuk dapat masuk } \\
\text { ke sistem }\end{array}$ & $\begin{array}{l}\text { Form Login jika berhasil akan } \\
\text { menampilkan dasboar } \\
\text { administrator }\end{array}$ & Sukses \\
\hline 2 & $\begin{array}{l}\text { Form Biaya Bahan } \\
\text { Baku }\end{array}$ & $\begin{array}{l}\text { Mengisi Form Biaya Bahan } \\
\text { Baku }\end{array}$ & $\begin{array}{l}\text { Data dapat ditampilkan di Tabel } \\
\text { Biaya Bahan Baku }\end{array}$ & Sukses \\
\hline 3 & $\begin{array}{l}\text { Form Biaya Tenaga } \\
\text { Kerja }\end{array}$ & $\begin{array}{l}\text { Mengisi Form Biaya Tenaga } \\
\text { Kerja }\end{array}$ & $\begin{array}{l}\text { Data dapat ditampilkan di Tabel } \\
\text { Biaya Tenaga Kerja }\end{array}$ & Sukses \\
\hline 4 & $\begin{array}{l}\text { Form Biaya } \\
\text { Overhead Pabrik }\end{array}$ & $\begin{array}{l}\text { Mengisi Form Biaya Overhead } \\
\text { Pabrik }\end{array}$ & $\begin{array}{l}\text { Data dapat ditampilkan di Tabel } \\
\text { Biaya Overhead Pabrik }\end{array}$ & Sukses \\
\hline 5 & $\begin{array}{l}\text { Form Biaya Non } \\
\text { Produksi }\end{array}$ & $\begin{array}{l}\text { Mengisi Form Biaya Non } \\
\text { Produksi }\end{array}$ & $\begin{array}{l}\text { Data dapat ditampilkan di Tabel } \\
\text { Biaya Non Produksi }\end{array}$ & Sukses \\
\hline 6 & Perhitungan & $\begin{array}{l}\text { Mengisi prosentase laba yang } \\
\text { diharapkan }\end{array}$ & $\begin{array}{l}\text { Dapat menampilkan harga produk } \\
\text { dan harga jual }\end{array}$ & Sukses \\
\hline 7 & $\begin{array}{l}\text { Halaman Hasil } \\
\text { Perhitungan }\end{array}$ & Klik Menu Hasil Perhitungan & $\begin{array}{l}\text { Dapat Menampilkan harga Hasil } \\
\text { perhitungan }\end{array}$ & Sukses \\
\hline
\end{tabular}

\section{KESIMPULAN}

1. Aplikasi pendukung penetapan harga digunakan untuk membantu para pengambil keputusan untuk menentukan harga jual produk, pada penelitian yang mengacu pada pembiayaan yang dikeluarkan pada proses produksi. 
2. Aplikasi pendukung penetapan harga dibuat dengan aspek biaya keseluruhan yang di kelurkan selama proses produksi.

3. Untuk penelitian selanjutnya dapat mempertimbangkan variabel lain selain pembiayaan untuk di perhitungkan dalam penetapan harga seperti harga produk kompetitor dan variabel-variabel lainnya.

\section{REFERENCES}

[1] Kementrian Perindustrian Republik Indonesia, (2016). Kontribusi UMKM Naik.

[2] http://www.kemenperin.go.id/artikel/14200/Kontribusi-UMKM-Naik diakses 8 Agustus 2018.

[3] Bank Indonesia (2015). Profil Bisnis Usaha Mikro Kecil dan Menengah (UMKM). http://www.bi.go.id/id/umkm/penelitian/nasional/kajian/Documents/Profil\%20Bisnis\%20UMKM.pdf diuduh pada 2 Agustus 2018.

[4] Kementrian Koperasi dan Usaha Kecil dan Menengah Republik Indonesia. (2015). Perkembangan Data Usaha Mikro, Kecil, Menengah (UMKM) dan Usaha Besar.

[5] http://www.depkop.go.id/ diakses 20 juli 2018.

[6] Mulyadi. 2015. Akuntansi Biaya, Edisi 5. Yogyakarta: Sekolah Tinggi Ilmu Manajemen YKPN.

[7] Tripustikasari, E., \& Wahyudi, R. (2018). Analisis Metode Penetapan Harga Produk Pada PT Serafood. Probisnis, 11(2), 22-31. Retrieved from http://ejournal.amikompurwokerto.ac.id/index.php/probisnis/article/view/737

[8] P. B. Jatmiko, A. P. Widodo, A. Sukmaaji. (2014). Sistem dan Aplikasi Penentuan Harga Jual Berdasarkan Biaya Total Pada CV. Terbit Terang. JSIKA Vol 3, No 1 .

[9] Pressman, Roger S., 2012, Rekayasa Perangkat Lunak, jilid I, Yogyakarta: Penerbit Andi.

[10] Lutfi, A. A., \& Wahyudi, R. (2017). Aplikasi Tracer Study Berbasis Website Responsive Pada Fakultas Pertanian Universitas Jendral Soedirman. Majalah Ilmiah INTI (Informasi Dan Teknologi Ilmiah), 13, 125-132. 